\title{
Comparative analysis of gamma-ray spectrometers applied to the study of the Irati Formation, São Paulo State
}

\author{
Gabrielle Roveratti, Daniel Marcos Bonotto, UNESP.
}

Copyright 2021, SBGf - Sociedade Brasileira de Geofísica

This paper was prepared for presentation during the $17^{\text {th }}$ International Congress of the Brazilian Geophysical Society held in Rio de Janeiro, Brazil, 16-19 August 2021.

Contents of this paper were reviewed by the Technical Committee of the $17^{\text {th }}$ International Congress of the Brazilian Geophysical Society and do not necessarily represent any position of the SBGf, its officers or members. Electronic reproduction or storage of any part of this paper for commercial purposes without the written consent of the Brazilian Geophysical Society is prohibited.

\begin{abstract}
Radiation has several applications both in science and in the daily life of mankind. This work describes the use of gamma ray spectrometry in the study of samples from the Irati Formation, sedimentary basin of Paraná. The technique allowed to measure the natural radiation emitted by radionuclides belonging to the decay series of ${ }^{238} \mathrm{U}\left(\mathrm{eU}={ }^{226} \mathrm{Ra}={ }^{214} \mathrm{Bi}\right)$ and ${ }^{232} \mathrm{Th}\left(\mathrm{eTh}={ }^{228} \mathrm{Th}={ }^{208} \mathrm{TI}\right)$ present in the analyzed samples. A comparison of the results obtained was done from readings conducted in three gamma detectors, portable, one solid state (BGO, Bismuth Germanate Oxide) and another the sodium iodide crystal (Nal(TI) - ORTEC), in addition to a benchtop, also $\mathrm{Nal}(\mathrm{TI})$ crystal (ORTEC). The research aimed identify the best detector to be used in the analysis of rock samples from the formation studied, which has provoked interest for the oil and gas sector. After the measurements, the statistical analysis of the data obtained for the radionuclides analyzed permitted identify significant linear relationships between eU and eTh in the readings obtained for both $\mathrm{Nal}(\mathrm{TI})$ scintillation detectors. Despite them, variable results were found among the gamma-ray spectrometers due to geometric factors, samples size and shape, as well analytical protocol adopted for the samples preparation. Compton effects in the gamma spectra apparently also affected the data acquisition by the $\mathrm{Nal}(\mathrm{TI})$ detectors as also described in this study.
\end{abstract}

\section{Introduction}

Studies focusing radioactivity and its application, benefits and uses have been applied, over the last decades, in various fields of the human activities, such as in scientific investigations and in the daily life.

In the last forty years, the radiometric surveys were performed with portable (manual and carborne) and airborne gamma spectrometers. The main purpose has been the mapping of the distribution of the elements that most contribute to the occurrence of natural radioactivity in different geological environments. The interpretation of this distribution has been successfully applied in basic geological mapping, prospecting for different mineral resources and in studies of radioactivity of the environment (Galbaith \& Saunders, 1983; Shives et al., 1997; Dickson \& Scott, 1997; Wilford et al., 1997).

Recently, radiometric surveys have been used to assess the extent and severity of the dispersion of artificial radioactive elements as a result of accidents in nuclear installations.

Pioneering works such as Adams and Gasparini (1970) and Doig (1968) provided the development of equipments, the calibration procedures and the methods for acquiring and interpreting field data. The field studies help to locate uranium deposits.

A major factor to be taken into account is the background radiation, because of the cosmic radiation which constantly reaches the planet, thus, it cannot be neglected during the readings performed in areas or samples of interest.

The study of the distribution and intensity of the rock radioactivity is of great importance for geophysicists and geochronologists, since they lend themselves to the selection of rocky materials for absolute geological dating and for the calculation of heat production inside the Earth. These studies also interest to exploratory geophysics in the search for radioactive mineral deposits. Measurements of the radioactive properties of naturally occurring materials indicate that a small level of radioactivity is present in all rocks and minerals.

The present work describes the use of radiometric methods for studying a geological formation occurring in the vicinity of the municipality of Rio Claro (SP), more specifically in Assistência District, where occurs the Irati Formation of the Paraná sedimentary basin (Figure 1).

\section{Study area}

In this work, two portable gamma-ray spectrometers, i.e. RS-230 from Radiation Solutions Inc. (BGO-Bismuth Germanate Oxide detector) and DigiDart LS from ORTEC (Nal(TI) detector) and a bench gamma-ray spectrometer using a $\mathrm{Nal}(\mathrm{TI})$ scintillation detector from ORTEC have been used in the analysis of samples that were collected from a quarry located in Assistência District, which exploits the Irati Formation from Paraná basin at São Paulo State, Brazil.

In São Paulo State, the Irati Formation usually consists of a 2.5 to 4 meters thick dolomitic bench, sometimes near the base of the formation, having on top about 20 to 30 
meters of a package consisting of alternating decimetric layers of black shale and limestone, more commonly dolomitic. The Irati existing in the central parts of the basin, known through surveys, has a heterogeneous thickness, ranging from 10 to 50 meters, on average, according to Petrobras reports. Such reports have pointed out that the lithology is very similar to that of outcrops, with the exception of the basal bank, present only in the area corresponding to the deep edge of the basin (Amaral, 1967).

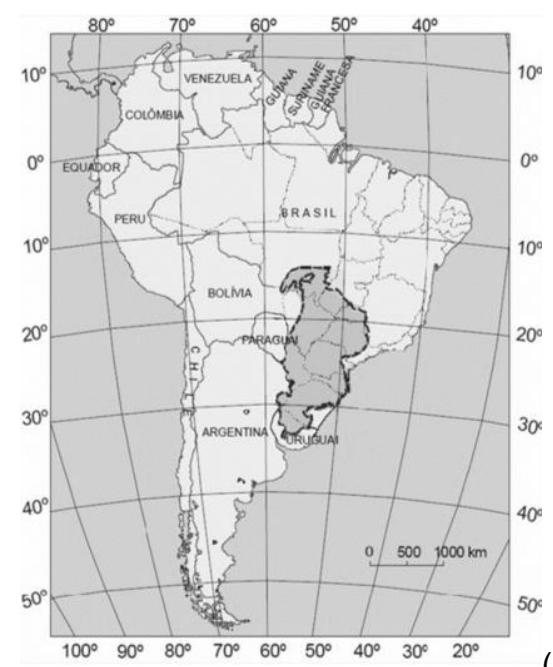

(a)

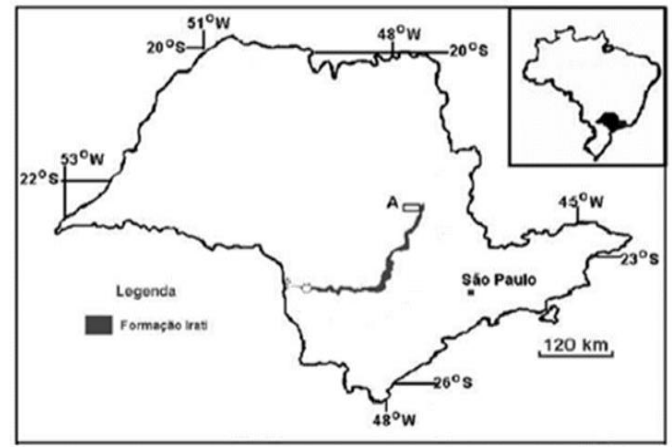

(b)

Figure 1 - Study Area location and sampling. (a) Paraná Basin location (modified from Silva, 2007) and (b) Irati Formation outcrop in São Paulo State (Chahud \& Petri, 2015).

In the state of São Paulo, from north to south, the outcrops occur at the following sites: Ipeúna, neighborhood of Assistência (Rio Claro), Limeira, Piracicaba, Laranjal, Guareí, around Angatuba, Itaí, Taquarituba and Taguaí (Figure 1). A single case (Assistência, Rio Claro) of a limestone fragment $40 \mathrm{~cm}$ long by $5 \mathrm{~cm}$ wide is observed, crossed obliquely into a layer of shale. It seems correspond to the fragmentation of a limestone layer in still plastic medium, and then one of the fragments was sunk in the clay mud. This aspect is described and illustrated in the work of Landim (1967) which makes a detailed description of these interesting occurrences (Amaral, 1967). The current interest in this formation has been increasing in order to better understand the occurrence of oil in limestone fractures (Silva, 2007), as illustrated in Photo 1.

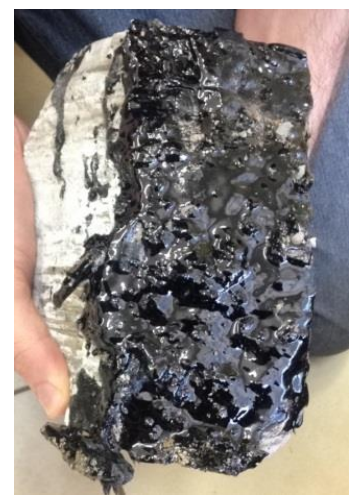

Photo 1 - Sample taken in a mapping conducted by a team from UNESPetro (Geosciences Center Applied to Petroleum - IGCE/Rio Claro) headed by geologist Dr. lata Anderson de Souza.

\section{Methods}

Portable gamma-ray spectrometers have up to $100 \mathrm{~cm}^{3}$ of $\mathrm{Nal}(\mathrm{TI})$ crystals as detectors, and various energy thresholds operated by circuits controllers. The limits can be adjusted for total count measurement and for energies close to 1.46 MeV $\left({ }^{40} \mathrm{~K}\right), 1.76 \mathrm{MeV}\left({ }^{214} \mathrm{Bi}\right)$, and 2.62 MeV $\left({ }^{208} \mathrm{TI}\right)$ for $\mathrm{K}$, eU (equivalent uranium $={ }^{226} \mathrm{Ra}$ ) and $\mathrm{eTh}$ (equivalent thorium $={ }^{228} \mathrm{Th}$ ) measurements, respectively. A gamma-ray emission source as a reference is sometimes used to adjust the instrument's gain. Threshold spectrometers with small crystal volumes are suitable for crude measurements at locations of total count anomalies.

The most modern gamma spectrometers are the socalled differential spectrometers. These usually have at least $350 \mathrm{~cm}^{3} \mathrm{Nal}(\mathrm{TI})$ detectors and display 1024-2048 data channels in the 0-3 MeV energy range. Automatic spectrum stabilization can be by a low-energy peak of a reference radionuclide (usually ${ }^{137} \mathrm{Cs}$ with $0.662 \mathrm{MeV}$ ), or by one of the natural radionuclide peaks $\left({ }^{40} \mathrm{~K}\right.$ with 1.46 $\mathrm{MeV}$ or ${ }^{208} \mathrm{TI}$ with $2.62 \mathrm{MeV}$ ).

Instruments can record the full spectrum as well as sum channels over wide energy windows for in situ estimation of $\mathrm{K}, \mathrm{eU}$ and eTh concentrations. Thousands of field measurements or hundreds of total energy spectra can be recorded in the instrument memory. The use of highvolume flicker crystals and multi-minute sampling intervals provide acceptable accuracy for quantitative analyses (Barbosa, 2016). Figures 2-5 illustrate a simplified diagram of the benchtop gamma-ray spectrometer and the detectors used in this work.

BGO detector (Fig. 5) was commercially manufactured in the 1970s, providing higher counting rates than $\mathrm{Nal}$ (its predecessor), thus, resulting in greater detection 
efficiency (PRT, 2019). Its use offers the option of fastest acquisition and best statistical accuracy in estimates of thorium, uranium and potassium. The main advantage of BGO is its high density $\left(7.3 \mathrm{~g} / \mathrm{cm}^{3}\right)$ and the high atomic number of the bismuth, which makes it the detector with the highest probability of volume interaction among the most commonly used (Tauhata et al., 2014).

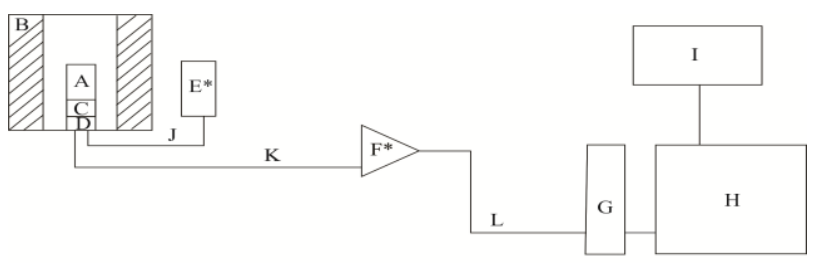

Figure 2 - Block diagram of the benchtop spectrometer, Nal(TI) - ORTEC. A - Nal(TI) 3'X3" Cristal, B - Lead shielding, C - Photomultiplier, D - Pre-amplifier, E - High Voltage source (1000V), $\boldsymbol{F}$ - ORTEC amplifier (model 485), $\boldsymbol{G}$ - ASPEC MCA ORTEC board (model 927), $\boldsymbol{H}$ Microcomputer, I - Printer, $\mathbf{J}, \boldsymbol{K}, \mathbf{L}$ - Cables. ${ }^{*} \mathrm{Nim}$ Bin is used to polarize the units.

(a)

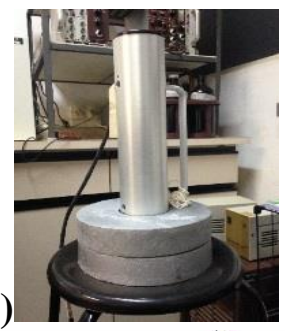

(b)
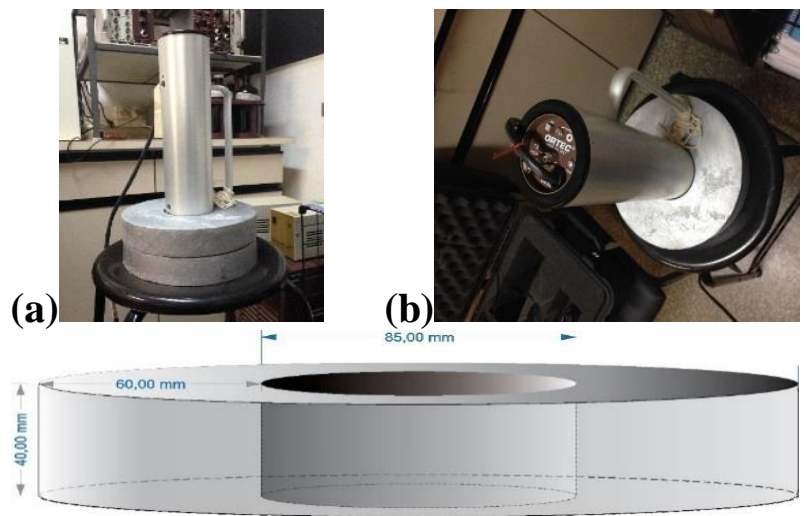

(c)

Figure 3 - $(\mathbf{a}, \boldsymbol{b})$ Illustration and positioning of the portable detector (Nal(TI) - DigiDart) in the shield for taking the calibration data and measurements to be performed. (c) Dimensions of lead rings used in the shielding of lateral radiation (Barbosa, 2016).

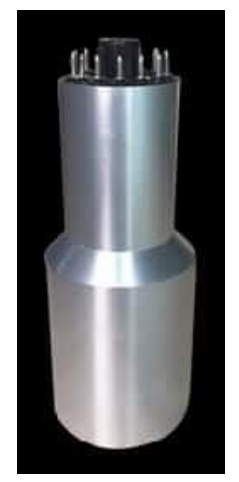

Figure 4 - Nal(TI) bench scintillation detector.
Another characteristic of BGO is that it is a pure inorganic scintillator, that is, it does not require an activator to promote the flickering process. This is because luminescence is associated with the optical transition of $\mathrm{Bi}^{3+}$. Compared to sodium iodide, it also has good mechanical and moisture resistance properties. The main disadvantages of BGO crystal are: its low light production, approximately 10 to $20 \%$ of that produced under equal conditions by $\mathrm{Nal}$ and its cost, which is two to three times higher than that of the latter (Tauhata et al., 2014).

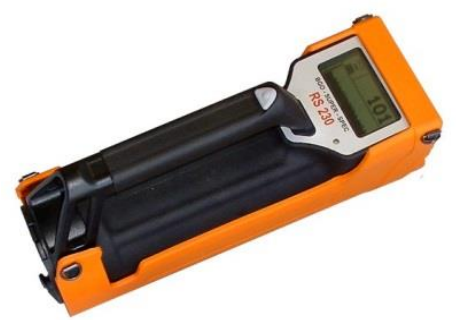

Figure 5 - Illustration of the BGO detector.

\section{Sampling}

In this work, the spectrometers were used in the analysis of samples taken from a quarry located in Assistência District, from Irati Formation, Paraná basin (Fig. 6).

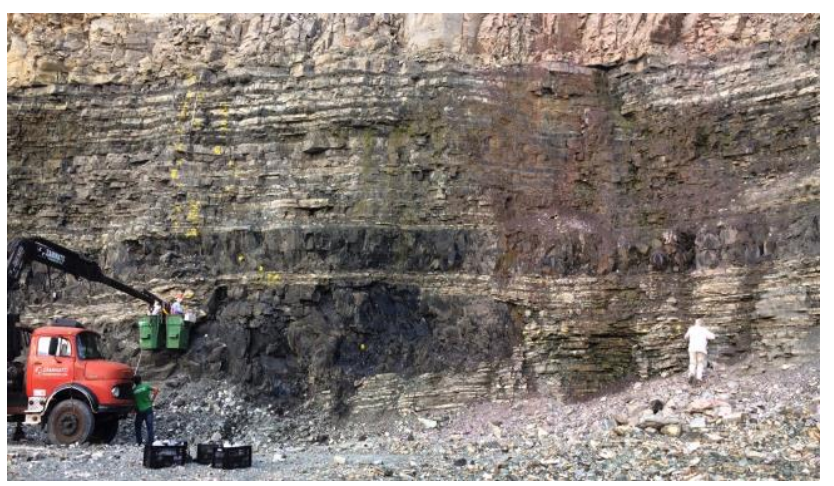

Figure 6 - Illustration of the Irati Formation in Assistência District (SP).

A total of 43 samples were collected, which were submitted to BGO analysis for 15 minutes in ASSAY mode. As demonstrated by Barbosa (2016), this was considered the optimal time to perform the measurements. The arrangement used in laboratory tests is illustrated in Photo 2. For other detectors, $\mathrm{Nal}(\mathrm{TI})$, the time used was approximately 8.5 hours $(30,000$ seconds).

\section{Results and Discussion}

The results obtained for $\mathrm{eU}$ and $\mathrm{eTh}$ readings were firstly written in a tablet format and compared in order to verify if there is high variability for these radioelements. Table 1 shows the statistical distribution for the BGO readings, while Table 2 reports the results obtained in the three gamma-ray spectrometers. 


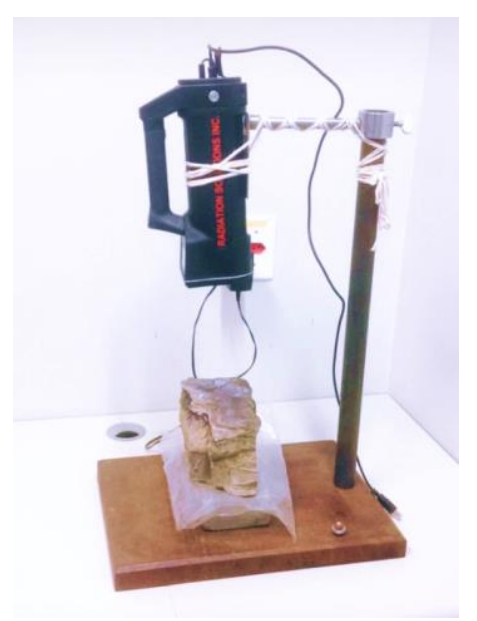

Photo 2 - Laboratory arrangement of the BGO.

Table 1 - BGO statistical data.

\begin{tabular}{c|c|c|c|c}
\hline \multicolumn{5}{c}{ eU (ppm) } \\
\hline Minimum & Maximum & Mean & Median & Mode \\
\hline 2.80 & 6.40 & 3.00 & 3.30 & 3.30 \\
\hline
\end{tabular}

\begin{tabular}{c|c|c|c|c}
\hline \multicolumn{5}{|c}{ eTh (ppm) } \\
\hline Minimum & Maximum & Mean & Median & Mode \\
\hline 9.60 & 11.60 & 10.00 & 10.60 & 10.60 \\
\hline
\end{tabular}

Initially, it was noticed that BGO presents results with low variability and very divergent from those of the $\mathrm{Nal}(\mathrm{TI})$ detectors. The values for the BGO spectrometer are always much lower than those obtained by the two Nal (TI) detectors and a possible reason for this is due to geometric factors. The crystals are solid circular cylinders of simpler manufacturing and encapsulation that can be mounted directly with the circular face over the photomultiplier. If the height/diameter cylinder ratio is not large, the light collecting properties are favorable in this geometry (Lima, 2006). Additionally, terrestrial radiation is attenuated at the source and by the material between the source and detector. The shape of the observed spectrum depends on the amount of attenuating material between the source and detector. With the increased attenuation, the photopeaks are reduced in relation to continuous energy. The measured spectra are therefore functions of the concentration and geometry of the source, the height of the above ground/rock detector, the thickness of any non-radioactive overload and the detector response function. In our experiments, the sample/detector distance was null for the $\mathrm{Nal}(\mathrm{TI})$ crystals, while it was about $15 \mathrm{~cm}$ for the sample/BGO detector. Another very important aspect is that crushed samples (230 mesh or $63 \mu \mathrm{m}$ ) were used in the $\mathrm{Nal}(\mathrm{TI})$ readings, whereas massif blocks were utilized for the BGO measurements. The latter certainly increases the gamma-ray attenuation, implying on lower readings.

The comparison between the readings of the two $\mathrm{Nal}(\mathrm{TI})$ detectors shows that for eU the values were higher in the portable detector only in 12 samples (28\% of all them), whilst for eTh this happened in 21 samples $(49 \%$ of all them). Despite these differences, significant correlations were found among the readings for both $\mathrm{Nal}(\mathrm{TI})$ scintillation detectors. For eU, the Pearson correlation coefficient is $r=0.85$ (Figure 7), whereas for $e T h, r=0.67$ (Figure 7).

When gamma-rays interact with matter, there are three primary ways their energies can be absorbed by materials. These are the photoelectric effect, Compton scattering, and pair production. In the Compton effect, a portion of the energy of the electromagnetic wave is given to the charged particle in an elastic, relativistic collision. In gamma-ray spectra, this yields a continuum zone of lower energy than that of the peak associated to the photoeletric effect. Photopeak associated to eU readings $\left({ }^{214} \mathrm{Bi}\right)$ in gamma-ray spectra is affected by continuum Compton of ${ }^{208} \mathrm{TI}$ photopeak. In our experiments, this factor was not took into account, possibly justifying the largest differences found in the eU readings obtained by both $\mathrm{Nal}(\mathrm{TI})$ crystals. Because the eTh readings are not affected by continuum Compton due to ${ }^{214} \mathrm{Bi}$ photopeak, the diferences were smaller between the measurements held by both $\mathrm{NaI}(\mathrm{TI})$ crystals.

Table 2 - Comparative data of the three spectrometers for eU and eTh readings.

\begin{tabular}{|c|c|c|c|}
\hline \multicolumn{4}{|c|}{ eU (ppm) } \\
\hline Sample & Portable-Nal(TI) & Bench-Nal(TI) & BGO \\
\hline $001 \mathrm{~A}$ & 19.12 & 65.08 & 3.0 \\
\hline 002 & 18.17 & 5.95 & 3.0 \\
\hline 003 & 13.78 & 30.34 & 3.3 \\
\hline $004 \mathrm{Tij}$ & 18.46 & 19.26 & 3.3 \\
\hline 005 & 9.78 & 17.42 & 3.2 \\
\hline 006 & $<9.65$ & 11.28 & 3.2 \\
\hline 008 (top) & 25.83 & 30.29 & 3.1 \\
\hline $\begin{array}{c}008 \\
\text { (bottom) }\end{array}$ & 23.67 & 15.04 & 3.3 \\
\hline 010 & 7.52 & 11.43 & 3.1 \\
\hline 011 & 3.08 & 10.35 & 3.5 \\
\hline 012 (top) & $<10.30$ & 27.66 & 3.4 \\
\hline $\begin{array}{c}012 \\
\text { (bottom) }\end{array}$ & $<8.48$ & 13.36 & 3.1 \\
\hline 013 & 5.98 & 5.34 & 3.5 \\
\hline 014 & 6.74 & 20.31 & 3.5 \\
\hline 015 & 12.88 & 23.82 & 3.4 \\
\hline 016 & 48.45 & 46.78 & 3.5 \\
\hline 016A & 22.63 & 17.64 & 3.4 \\
\hline 017 & 17.76 & 33.71 & 3.1 \\
\hline 018 & 18.75 & 23.97 & 3.4 \\
\hline 019 & $<8.04$ & 5.43 & 3.0 \\
\hline 020 & 33.80 & 34.78 & 3.5 \\
\hline 021 & 11.41 & 14.37 & 3.7 \\
\hline 022 & 23.32 & 39.61 & 3.2 \\
\hline 023 (mix) & 22.35 & 22.32 & 3.6 \\
\hline $023 \mathrm{~A}$ & 200.57 & 115.72 & 3.4 \\
\hline 024 & 28.88 & 34.44 & 3.5 \\
\hline 025 & $<15.30$ & 20.44 & 4.2 \\
\hline 026 & 48.02 & 57.01 & 4.1 \\
\hline $027 \mathrm{Tij}$ & 48.80 & 46.96 & 5.2 \\
\hline 028 & 25.79 & 28.87 & 3.5 \\
\hline 030 & 66.46 & 59.57 & 3.7 \\
\hline
\end{tabular}




\begin{tabular}{|c|c|c|c|}
\hline 032 & 22.24 & 30.84 & 3.2 \\
\hline 033 & 11.27 & 10.73 & 3.5 \\
\hline 034 & 16.00 & 29.79 & 3.3 \\
\hline 034A & 41.71 & 40.36 & 3.6 \\
\hline 035 (top) & 19.17 & 23.40 & 3.4 \\
\hline $\begin{array}{c}035 \\
\text { (bottom) }\end{array}$ & 15.38 & 22.51 & 3.2 \\
\hline 036 & 2.83 & 37.94 & 3.3 \\
\hline 037 & 31.82 & 35.63 & 3.5 \\
\hline 038 & 40.78 & 50.93 & 3.1 \\
\hline 039 (top) & $<44.18$ & 47.34 & 3.3 \\
\hline $\begin{array}{c}039 \\
\text { (middle) }\end{array}$ & 21.83 & 31.28 & 3.0 \\
\hline $\begin{array}{c}039 \\
\text { (bottom) }\end{array}$ & $<40.30$ & 41.88 & 3.2 \\
\hline \multicolumn{4}{|c|}{ eTh (ppm) } \\
\hline Sample & Portable-Nal(TI) & Bench-Nal(TI) & BGO \\
\hline $001 \mathrm{~A}$ & 43.09 & 17.78 & 10.70 \\
\hline 002 & 18.95 & 52.68 & 10.60 \\
\hline 003 & 25.28 & 23.55 & 10.20 \\
\hline $004 \mathrm{Tij}$ & 31.48 & 13.41 & 10.80 \\
\hline 005 & $<53.26$ & 26.11 & 10.50 \\
\hline 006 & $<51.87$ & 28.85 & 10.40 \\
\hline 008 (top) & 116.77 & 7.85 & 11.00 \\
\hline $\begin{array}{c}008 \\
\text { (bottom) }\end{array}$ & 61.9 & 5.43 & 10.60 \\
\hline 010 & 9.58 & 19.48 & 10.70 \\
\hline 011 & 15.3 & 23.40 & 10.30 \\
\hline 012 (top) & $<54.25$ & 29.86 & 10.30 \\
\hline $\begin{array}{c}012 \\
\text { (bottom) }\end{array}$ & $<46.35$ & 4.17 & 10.50 \\
\hline 013 & 18.39 & 23.85 & 10.60 \\
\hline 014 & 22.29 & 33.39 & 10.20 \\
\hline 015 & 31.78 & 28.07 & 10.70 \\
\hline 016 & 98.19 & 94.1 & 10.50 \\
\hline $016 A$ & 56.27 & 55.27 & 10.20 \\
\hline 017 & $<73.6$ & 104.13 & 10.60 \\
\hline 018 & 73.75 & 80.33 & 10.20 \\
\hline 019 & $<45.77$ & 57.94 & 10.70 \\
\hline 020 & 26.93 & 31.24 & 10.20 \\
\hline 021 & 51.9 & 59.85 & 10.70 \\
\hline 022 & 95.84 & 83.81 & 10.80 \\
\hline 023 (mix) & 76.6 & 77.89 & 10.60 \\
\hline $023 \mathrm{~A}$ & 357.09 & 135.71 & 11.20 \\
\hline 024 & 70.96 & 77.37 & 10.60 \\
\hline 025 & $<71.07$ & 66.03 & 11.00 \\
\hline 026 & 91.96 & 92.23 & 10.50 \\
\hline $027 \mathrm{Tij}$ & 87.58 & 92.20 & 10.60 \\
\hline 028 & 74.55 & 92.5 & 10.00 \\
\hline 030 & 123.3 & 96.34 & 10.80 \\
\hline 032 & $<63.2$ & 65.25 & 10.30 \\
\hline 033 & 61.76 & 68.83 & 10.60 \\
\hline 034 & 44.07 & 47.08 & 11.30 \\
\hline 034A & 59.87 & 48.24 & 11.10 \\
\hline 035 (top) & $<51.1$ & 62.11 & 10.80 \\
\hline $\begin{array}{c}035 \\
\text { (bottom) }\end{array}$ & 79.56 & 70.56 & 10.30 \\
\hline 036 & $<68.13$ & 70.13 & 10.30 \\
\hline
\end{tabular}

\begin{tabular}{cccc}
\hline $\mathbf{0 3 7}$ & 24.4 & 29.68 & 10.70 \\
$\mathbf{0 3 8}$ & 64.26 & 62.42 & 10.70 \\
$\mathbf{0 3 9}$ (top) & $<146.79$ & 171.98 & 10.90 \\
$\mathbf{0 3 9}$ & 69.4 & 68.33 & 10.50 \\
(middle) & & & \\
$\mathbf{0 3 9}$ & $<137.85$ & 132.64 & 9.60 \\
\hline (bottom) & & \\
\hline
\end{tabular}

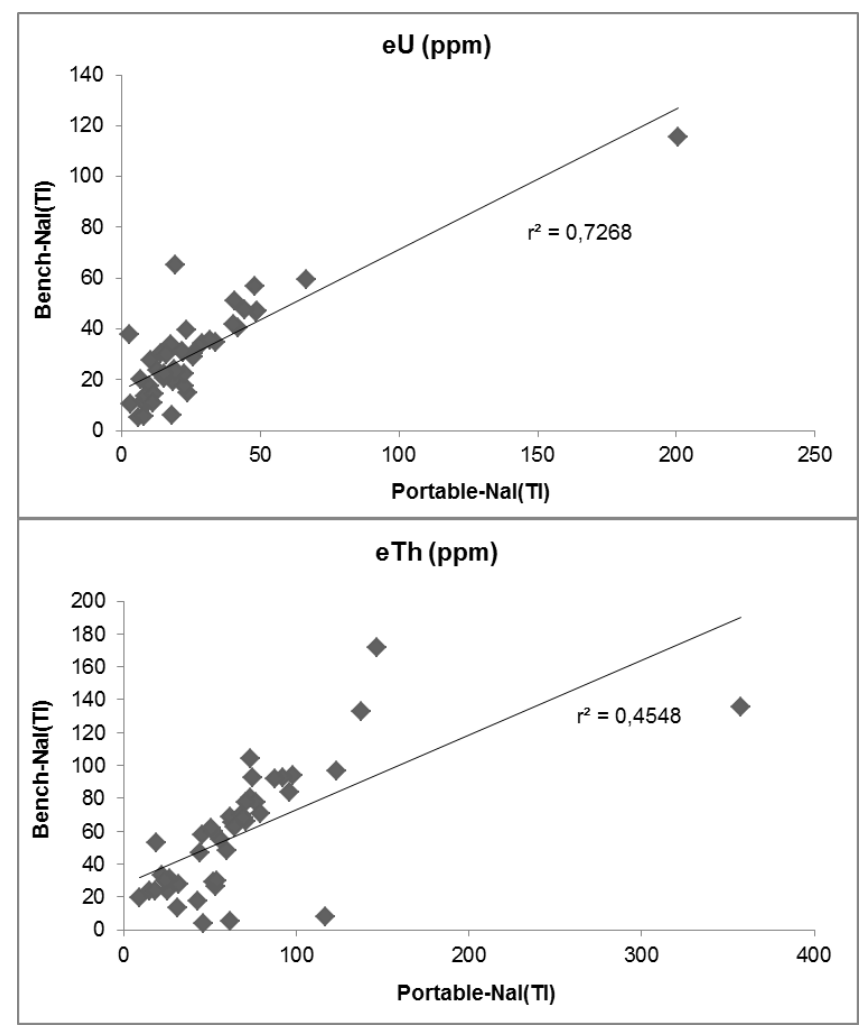

Figure 7 - Relationships of the eU and eTh data obtained in the $\mathrm{Nal}(\mathrm{TI})$ gamma-ray spectrometers.

Other eU and eTh data have been reported in the literature for the Irati Formation, but utilizing high resolution High Purity Germanium (HPGe) gamma-ray spectrometers. In Cruzeiro Limestone Mining, at Limeira city, São Paulo State, Carlos et al. $(2004,2008)$ utilized the superposition of the lines of ${ }^{234} \mathrm{Th}$ and ${ }^{234} \mathrm{~Pa}$ (total of $63.3 \mathrm{keV}$ ) for ${ }^{238} \mathrm{U}$, and found $\mathrm{eU}=0.54-12.69 \mathrm{ppm}$. For ${ }^{232} \mathrm{Th}$, it was used ${ }^{212} \mathrm{~Pb}(238.6 \mathrm{keV}),{ }^{212} \mathrm{Bi}(727.3 \mathrm{keV})$ and ${ }^{208} \mathrm{TI}(583.2 \mathrm{keV}$ and $860.6 \mathrm{keV})$ for yielding eTh $=$ 0.2-15.2 ppm. In Paraná State, Ferreira (2008) reported the following values: $\mathrm{eU}=1.4-57.2 \mathrm{ppm}$; $\mathrm{eTh}=0.7-12.4$ $\mathrm{ppm}$. More detailed investigation will be realized for identifying such data variability compared to our results, i.e. if they are related to lithological aspects or analytical procedures utilized.

\section{Conclusion}

Different gamma-ray spectrometers have been utilized in the analysis of samples providing from a quarry located in Assistência District, which exploits the Irati Formation from Paraná basin at São Paulo State, Brazil. The BGO (Bismuth Germanate Oxide) detector presented results with low variability and very divergent from those of the 
$\mathrm{Nal}(\mathrm{TI})$ detectors, suggesting strong influence of geometric factors, size and shape of the samples and techniques adopted for sample preparation. The readings obtained with the portable and bench $\mathrm{Nal}(\mathrm{TI})$ scintillation detectors also varied, possibly related to Compton effects in the gamma spectra mainly caused by the ${ }^{208} \mathrm{TI}$ photopeak in the eU readings. Proper data treatment will be realized for clarifying if this is the case and also for identifying possible reasons of different results reported in the literature for the same geological formation.

\section{Acknowledgments}

The authors thank PRH 40 from ANP-FINEP-UNESP-Rio Claro for the MSc scholarship granted to GR as well the Project "Influence of magmatism in carbonatic lake rocks: analogues for Libra area" developed under the partnership of Petrobras-UNESP-FUNDUNESP for providing access to the samples for gamma-ray analysis.

\section{References}

AMARAL, S. E. do. Geologia e petrologia da formação Irati (Permiano) no estado de São Paulo. Livre Docencia. USP. 20p., 1967.

ADAMS, J. A. S.; GASPARINI, P. Gamma rays spectrometry of rocks. Amsterdam, London, New York: Elsevier, 1970. p. 1-308.

BARBOSA, E. Q. Calibração de detectores cintiladores e sua aplicação em medidas radiométricas. Tese de Mestrado. UNESP. 63., 2016.

CARLOS, D. U. ; RIBEIRO, F. B. ; SAAD, A. R. . Distribuição da radioatividade natural na Formação Iratí na região de Limeira, SP. Revista Brasileira de Pesquisa e Desenvolvimento, São Paulo, v. 4, n.3, p. 1230-1235, 2002.

CARLOS, D. U., RIBEIRO, F. B., SAAD, A. R, Nieolai S. H. A, "Radioactivity distribution in some Permian sediments from the Irati and Corumbataí Formations of the Paraná Basin, Southeastern Brazil," Applied Radiation and Isotopes, 60, pp. 63-67 (2004).

CHAHUD, Artur; PETRI, Setembrino. Geologia e paleontologia da Formação Irati (Eopermiano, Bacia do Paraná) no Rio Passa Cinco, Estado de São Paulo. Brazilian Geographical Journal: Geosciences and Humanities research medium, Ituiutaba, MG, v. 6, n. ja/ju 2015 , p. 110-120, 2015. Disponível em: < http://www.seer.ufu.br/index.php/braziliangeojournal/articl e/view/27480 >

DICKSON, B. L.; e SCOTT, K. M. 1997. Interpretation of aerial gamma ray surveys adding the geochemical factors. s.I. : AGSO J. Austr. Geol. Geophys, 1997.
FERREIRA, A. de O. Distribuição de radionuclídeos em um afloramento de sedimentos permianos da formação Irati na Bacia do Paraná. Dissertação (Mestrado em Física) - Universidade Estadual de Londrina, Centro de Ciências Exatas, Programa de Pós-Graduação em Física, 2008 I Adernar de Oliveira Ferreira. - Londrina, 2008. $108 f$.

GALBAITH, J. H.; SAUDERS, D. F. 1983. Rock classification by charecteristics of aerial gamma ray measurements. s.I. : J. Geochem., 1983. 18, 49-73.

LANDIM, P. M. B . O Grupo Passa Dois $(P)$ na bacia do rio Corumbataí, Tese para concurso de doutoramento apresentada à Fac. de Fil., Ci. e Cetr. da U.S.P. 1967.

LIMA, C. A. 2006. Avaliação da performance dos detetores lodeto de Sódio $\mathrm{Nal}(\mathrm{TI})$ em centrais nucleares. (Tese de Doutorado). Rio de Janeiro (RJ) : Universidade federal do Rio de Janeiro, 2006. 109p.

PRT, 2019. RS-230 BGO Handheld Spectrometer Radiation Solutions. Available online at < https://www.peo-radiation-technology.com/wpcontent/uploads/sites/4/2015/07/rs_15_rs230brochure1.p df $>$

SHIVES, R. B. K.; CHARBONNEAU, B. W.; FORD, K. L. 1997. The detection of potassic alternation by gamma ray spectrometry recognition of alternation related to mineralization. Toronto - Canada : Proceedings of the Fourth Decennial International Conference on Mineral Exploration (Exploration 97), 1997. 14-18 September.

SILVA, C. G. A. da. Caracterização geoquímica orgânica das rochas geradoras de petróleo das formações Irati e Ponta Grossa da Bacia do Paraná. 2007.

TAUHATA, L.; SALATI, I P.; DI PRINZIO, R.; DI PRINZIO, A. 2014. Radioproteção e Dosimetria, Fundamentos. s.I. : IRD/CNEN, 2014. 10ª revisão

WILFORD, J. R.; BIERWIRTH, P. N.; GRAIG, M. A. 1997. Application of airborne gamma ray spectrometry in soil regolith mapping and applied geomorphology. s.I. : AGSO Austr. Geol. Geophys, 1997. 17 (2), 201-216.

DOIG, R. The natural gamma-ray flux: in

siyu analysis. Geophysics, v. 33, n. 2, p. 311-328, 1968. 